Братко А. В., канд. військ. наук, доцент

(0000-0001-5503-3318)

Національна академія Державної прикордонної служби України імені Богдана Хмельницького, Хмельницький

\title{
Удосконалення оборонного планування у Державній прикордонній службі України
}

Резюме. У статті досліджені сучасні підходи та наведені певні рекомендації щодо удосконалення планування у Державній прикордонній службі України на основі спроможностей. Таке планування дасть змогу якісніше планувати оперативно-службову діяльність прикордонного відомства та забезпечувати активніше співробітництво України з НАТО з метою досягнення критеріїв, необхідних для набуття повноправного членства в Альянсі.

Ключові слова: планування; спроможності; оперативно-службова діяльність; сили та засоби; Державна прикордонна служба України.

Постановка проблеми. Події останніх років змінили умови, у яких функціонує Державна прикордонна служба України (далі - ДПС України), що призвело до нагальної потреби, а саме удосконалення планування оперативно-службової діяльності та подальшого розвитку (реформування) відомства.

Планування в ДПС України на основі спроможностей $є$ одним із перспективних методів планування у сфері забезпечення безпеки державного кордону, особливістю якого $€$ розвиток спроможностей сил для ефективної протидії загрозам i ризикам як воєнного, так i невоєнного характеру 3 урахуванням імовірних сценаріїв розвитку конфліктних (кризових) ситуацій на довгострокову перспективу. Цей метод планування $€$ основним в країнах - членах HATO.

Аналіз останніх досліджень i публікацій. У наукових працях [1-7] проведено дослідження щодо:

організації і планування діяльності Збройних Сил України (далі - 3С України) та інших складових сектору безпеки і оборони; проблем розвитку спроможностей сил безпеки і оборони;

стратегічного планування на основі спроможностей за підходами управління, які орієнтовані на результат;

наявного стану та подальшого розвитку системи оборонного планування в 3С України.

У монографії [8], яка присвячена оборонному менеджменту, викладені новітні підходи до впровадження у Міністерстві оборони (МО), ЗС України та інших складових сил оборони системного підходу до оборонного менеджменту.
Проте залишається невирішеним актуальне питання щодо впровадження планування на основі спроможностей в діяльність ДПС України.

Мета статті $\epsilon$ удосконалення планування оперативно-службової діяльності органів управління ДПС України на основі їx спроможностей.

Викладення основного матеріалу. Планування оперативно-службової діяльності на основі спроможностей потребує вдосконалення, передусім, за функціональною ознакою. Адже функціональна група спроможностей, відповідно до Порядку організації та здійснення оборонного планування в Міністерстві оборони України, Збройних Силах України та інших складових сил оборони, затвердженого наказом МО України від 22.12.2020 № 484, являє собою “сукупність спроможностей складових сил оборони, поєднаних в ієрархічну структуру відповідно до їх функціонального призначення".

Функції та завдання, що мають виконуватись під час очікуваних (вірогідних, майбутніх) дій сил і засобів, трансформуються у вимоги до спроможностей, на підставі чого планується їх створення, підтримання та розвиток.

Планування в ДПС України на основі спроможностей передбачає створення, розвиток та підтримання оптимального складу необхідних спроможностей в межах наявних ресурсів. Однак матеріальні ресурси не завжди є визначальним фактором розвитку спроможностей.

Ефективними шляхами нарощування спроможностей може бути удосконалення законодавчої бази, основ застосування, структур частин і підрозділів ДПС України, 
впровадження нових форм і методів оперативно-службової діяльності, поліпшення системи відбору на військову службу, навчання, підготовка та мотивація персоналу відомства тощо.

На відміну від планування на основі загроз, планування на основі спроможностей в ДПС України потребує зосередження зусиль не на створенні нових організаційних структур для забезпечення противаги правопорушенням, a на розвитку спроможностей наявних сил для ефективного виконання визначених їм завдань за функціональним призначенням.

Основними завданнями планування оперативно-службової діяльності в ДПС України на основі спроможностей $є$ [8]: оцінювання середовища у сфері забезпечення безпеки державного кордону, визначення засад, цілей та основних завдань ДПС України в системі державної політики у сфері оборони держави, пріоритети і напрями розвитку сил безпеки державного кордону 3 урахуванням реальних і потенційних загроз у прикордонній сфері, демографічних i фінансово-економічних можливостей держави;

визначення вимог до спроможностей, структури, чисельності персоналу, кількісних і якісних показників ОВТ, інших видів МТ3, прикордонної підготовленості особового складу сил прикордонного відомства (формування перспективного складу ДПС України, який задовольняє вимогам щодо необхідних спроможностей 3 урахуванням можливостей держави задовольнити потреби у забезпеченні безпеки державного кордону);

оцінювання стану готовності сил ДПС України до виконання завдань iз забезпечення безпеки державного кордону (оцінювання наявних спроможностей ДПС України щодо виконання завдань за всіма визначеними сценаріями), а також результати виконання заходів 3 їхнього розвитку за попередній період;

формування комплексного документа 3 розвитку спроможностей ДПС України та потреби на розвиток спроможностей ДПС України у видатках Державного бюджету України, оцінювання ризиків; планування ресурсного забезпечення ДПС України (формування пропозицій до державного оборонного замовлення, планування закупівель продукції, робіт i послуг, зокрема на особливий період); планування заходів 3 мобілізаційної підготовки у ДПС України;

організація виконання завдань та заходів програм і планів, оцінювання стану досягнення спроможностей.

Принципами такого планування на основі спроможностей в літературі є [9]:

реалістичність, яка полягає в збалансованості вартості заходів із досягнення спроможностей та виділеними коштами;

результативність, яка полягає у досягненні визначених цілей завдяки виконанню завдань i заходів у плановий період у межах виділених коштів;

ефективність, яка полягає в оптимальному співвідношенні витрачених ресурсів і досягнутого результату;

централізація управління плануванням для забезпечення збалансованого розвитку складових сил оборони;

безперервність управління плануванням та моніторингу спроможностей;

системність і паралельність процесів планування та моніторингу для забезпечення оперативності процесу управління розвитком спроможностей;

об’єктивність і колегіальність під час підготовки пропозицій для прийняття рішень у процесі планування;

цілісність, яка забезпечується взаємоузгодженням документів планування розвитку складових сил оборони на довго-, середньо- та короткостроковий період 3 урахуванням їх функціонального призначення;

єдине наскрізне планування створення нових i модернізація існуючих видів озброєння, військової та спеціальної техніки, виробничих потужностей для їх розроблення, виготовлення, а також освоєння i впровадження нових технологій військового призначення;

узгодженість планування в ДПС України із стратегічним плануванням застосування сил оборони, заходами мобілізаційної підготовки національної економіки, системи життєзабезпечення населення і території держави до оборони; відкритість інформації про цілі, пріоритети, орієнтири планування та прозорість використання ресурсів.

Вихідними даними для планування є: визначені законами України засади внутрішньої і зовнішньої політики, зокрема у сфері оборони держави;

визначені прогнозовані загрози національній безпеці та національним 
інтересам України, стратегічні цілі та основні завдання політики національної безпеки у сфері оборони держави та забезпечення безпеки державного кордону, а також уточнені, за необхідності, завдання сил складових сектору безпеки і оборони;

висновки за результатами аналізу досягнень воєнної науки та новітніх технологій військового призначення, досвіду застосування ДПС України та інших складових сектору безпеки i оборони у воєнних діях та міжнародних операціях 3 підтримання миру та безпеки;

орієнтовні прогнозні показники можливостей держави у задоволенні потреб оборони людськими, фінансовими та матеріально-технічними ресурсами (показники виробництва військової техніки та озброєння підприємствами оборонно- промислового комплексу в мирний час, після введення в дію мобілізаційного плану національної економіки України на особливий період, закупівлі за кордоном, виробництва в кооперації, лізингу та інших форм військовотехнічного співробітництва);

затверджена за результатами огляду стану загальна структура, склад та організація ДПС України (для довгострокового планування - модель (обрис) майбутніх сил ДПС України).

Ïx оборонний огляд передбачає проведення таких основних процедур (рис. 1) [8]: оцінювання середовища безпеки; планування сил; планування ресурсів; оцінювання ризиків; формування перспективної моделі (структури) ДПС України; п підготовка програмних документів їх розвитку.

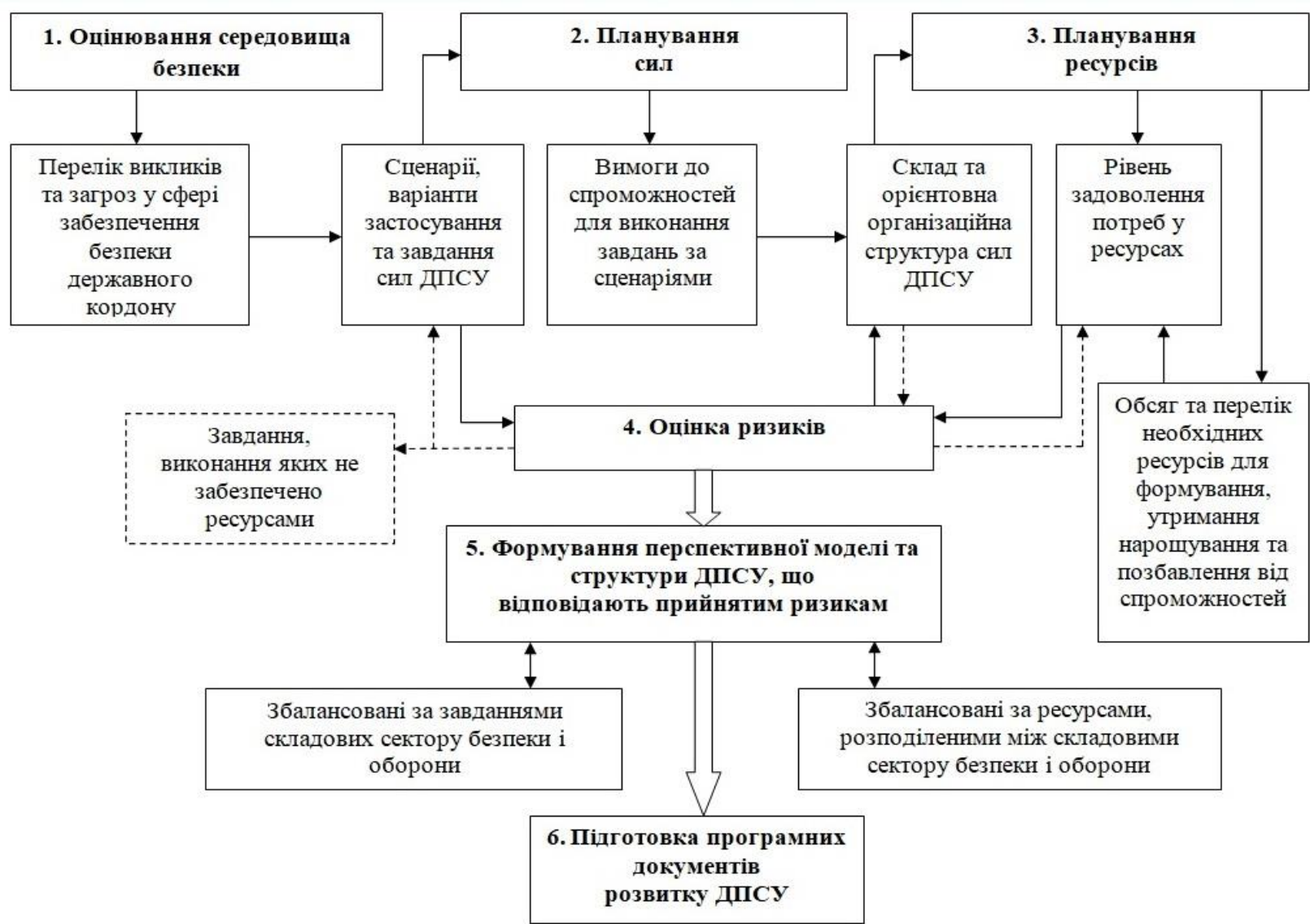

Рис. 1. Процедури оборонного огляду ДПС України

За їх результатами опрацьовується перспективний склад та організаційна структура сил, які відповідають завданням ДПС України та збалансованим ресурсам, розділеними між складовими сектору безпеки i оборони, а також програмні документи довго- та середньострокового планування.

Оцінювання наявних спроможностей (оперативних, бойових, спеціальних) здійснюється департаментами Адміністрації
ДПС України на стратегічному, оперативному, тактичному рівні, командирами, начальниками, керівниками структурних підрозділів та організацій під час огляду, огляду спроможностей (1 раз на 23 роки за рішенням Голови ДПС України), а також за необхідністю. Воно здійснюється за усіма базовими компонентами (складовими) спроможностей та передбачає оцінювання: 
чинних доктринальних документів, які застосовуються (для підготовки, застосування, організації повсякденної діяльності підрозділу (структурного елементу);

організаційної структури і складу наявних підрозділів ДПС України щодо їх здатності виконувати завдання за кожною ситуацією з необхідним рівнем ефективності;

рівня підготовки персоналу до виконання завдань за призначенням;

забезпеченості необхідними зразками озброєння та військової техніки для виконання завдань за ситуаціями, 3 урахуванням їх технічного стану та термінів експлуатації;

стану та здатності систем матеріального та технічного забезпечення (логістики), медичного забезпечення до виконання завдань за ситуаціями, зокрема наявність запасів;

якості військової освіти та науки, іï здатності забезпечити належний рівень професійної підготовки персоналу i обгрунтування розвитку та застосування ДПС України; наявності

кваліфікованого та мотивованого військового (цивільного) персоналу;

наявної прикордонної інфраструктури i ii здатності забезпечувати життєдіяльність прикордонних підрозділів та виконання ними завдань за призначенням; HATO.

рівня сумісності 3 підрозділами сил

Розвиток спроможностей здійснюється завдяки розвитку (вдосконаленню) базових компонентів (складових) спроможностей.

Розвиток ОВТ не єдиний шлях розвитку спроможностей. Необхідного ефекту в деяких випадках можливо досягти поліпшенням інших базових компонентів (складових) спроможностей, які не потребують значних ресурсів, зокрема удосконаленням (зміною) доктрин, засад застосування, організаційних структур, поліпшення системи відбору, навчання, підготовки та мотивації персоналу.

Основні етапи розвитку спроможностей включають:

визначення (опис) спроможності (capability definition);

визначення стандартів, необхідних для розвитку спроможності та формування переліку військових вимог (сил і засобів) (definition of standards and military requirements);

закупівлю (постачання) необхідних ОВТ та MT3 (procurement); розроблення настанов та підготовку персоналу (implementation through instruction and training); бойове злагодження (навчання) перед застосуванням (deployment preparations);

розгортання та застосування спроможності (deployment / engagement of the capabilities);

оцінювання та висновки (аналіз та опрацювання пропозицій щодо коригування цільових пакетів (документів 3 розвитку) спроможностей (lessons learned) [9].

Спроможності ДПС України можна розвивати через:

аналіз та оцінювання розвитку воєннополітичної обстановки для визначення переліку реальних і потенційних воєнних загроз, уточнення варіантів імовірних сценаріїв i ситуацій для планування застосування сил з урахуванням ескалації цих загроз;

визначення завдань за ситуаціями, зокрема кінцевої мети ведення прикордонних операцій;

опис умов виконання визначених завдань;

визначення алгоритмів дій сил і засобів у певних умовах (ситуаціях);

визначення вимог до спроможностей сил i засобів, запланованих для виконання визначених завдань.

Аналіз та оцінювання розвитку восннополітичної обстановки для визначення переліку реальних i потенційних загроз воєнного характеру на державному кордоні передбачає:

аналіз міждержавних відносин, їх змісту i спрямованості, намірів держав або інших суб'єктів щодо вирішення політичних питань, поглядів їх воєнно-політичного керівництва на роль воєнно-силових методів у вирішенні цих питань;

оцінювання впливу глобальних економічних, політичних, демографічних та інших проблем на безпеку України у сфері забезпечення безпеки державного кордону;

розгляд військових планів та приготувань окремих держав, політичних суб'єктів, оцінювання рівня небезпеки, що походить від окремих воєнно-політичних конфліктів чи конфліктних територій;

3'ясування рівня розвитку способів i засобів збройної боротьби та зусиль окремих держав для їх удосконалення;

дослідження процесу утворення i динаміки розвитку воєнно-політичних союзів (блоків) та аналіз їх цілей;

моніторинг виникнення нових зовнішніх і внутрішніх політичних та (або) економічних умов, які загрожують національним інтересам 
України, аналіз тенденцій їх розвитку на державному кордоні;

оцінювання розвитку інформаційного простору та його впливу на прикордонну безпеку;

оцінювання інших суб'єктів, які впливають на стан і систему забезпечення прикордонної безпеки в довготривалій перспективі.

Оцінювання воєнно-політичної обстановки та перспектив іï розвитку завершується складанням Переліку викликів і загроз прикордонній безпеці, сценаріїв застосування сил ДПС України, можливих завдань і способів їх виникнення на основі прогнозних характеристик імовірності виникнення можливих кризових ситуацій воєнного характеру та їх негативного впливу на національні інтереси України.

Результатом виконання цього кроку $\epsilon$ визначення переліку викликів та загроз у воєнній сфері та сценаріїв їх розвитку на державному кордоні на довгостроковий період.

Розроблення сиенаріїв застосування сил ДПС Украӥни передбачає уточнення завдань, застосування опису географічних районів, визначення ймовірного просторового розмаху воєнних (бойових) дій, визначення протиборчих сил, їх спроможності, військових цілей та відповідних завдань.

Для формування ймовірних сценаріїв $\mathrm{i}$ ситуацій можливого застосування сил ДПС України враховують вимоги доктрин, інших стратегічних і концептуальних документів, актів Президента України тощо.

Сценарій має містити низку обов'язкових елементів: об'єкт впливу загрози воєнного характеру та можливі цілі сторін, опис умов виникнення загрози, можливих суб'єктів, які братимуть участь у їі реалізації, масштаби реалізації, сили і засоби, які можуть бути задіяні в цьому сценарії, інші особливості його реалізації.

Сценарії конкретизують у ситуаціях, які описують особливості застосування сил ДПС України та засобів, тривалість і наслідки застосування сили, обсяг сил прикордонного відомства, які будуть задіяні в разі виникнення певної ситуації.

Для забезпечення уніфікованого підходу до процесу уточнення сценаріїв, використовують шаблони, структура яких містить такі елементи: загальний опис сценарію; припущення щодо застосування військової сили; політичні та воєнні цілі, яких потрібно досягти; фізико-географічні, військові та цивільні умови; припущення щодо підтримання сил; загальний задум операції сил.

Пріоритети кожного сценарію визначають експертно-аналітичним шляхом відповідно до ймовірності виникнення та масштабів наслідків для України.

Результатом виконання цих заходів можуть бути висновки 3 оцінювання воєннополітичної обстановки, характеристика викликів i загроз, пропозиції до переліку сценаріїв застосування сил ДПС України, перелік можливих ситуацій для планування сил.

Визначення завдань, які мають бути виконані для нейтралізації конфліктної (кризової) ситуації певного сценарію. Завдання можуть бути сформульовані лише після опису та аналізу ситуації (або іiі варіанта) певного сценарію, який потребує застосування (залучення) відповідних складових сил і засобів ДПС України.

Завдання вважають прийнятним, якщо для його виконання залучають мінімальну кількість сил і засобів, очікувані витрати при цьому мінімальні, а виконання можливе в межах відповідних нормативів (часу, фізичних характеристик досягнення тощо).

Завдання для спільного виконання ДПС України, ЗС України та іншими складовими сил сектору безпеки і оборони за визначеними сценаріями (ситуаціями) вирішують на основі вказаних у чинних доктринах i нормативно-правових актах, бойових статутах, настановах тощо завдань 3 питань підготовки та застосування підрозділів ДПС України, ЗС України та інших складових сектору безпеки i оборони (стандартних завдань), або визначених для прогнозованих за ситуаціями викликів, ризиків і загроз.

В описі цих завдань мають бути вказані заходи, які виконуватиме ДПС України, ЗС України та інші складові сили безпеки i оборони для нейтралізації (запобігання, ліквідації наслідків тощо) конфліктної (кризової) ситуації певного сценарію.

Залежно від рівня завдань визначають їх виконавців:

національні стратегічні - на рівні держави обов'язкові для всіх сил сектору безпеки і оборони;

стратегічні (як частина національних або самостійних) - Адміністрація ДПС України, регіональні управління ДПС України; 
оперативні (як частина стратегічних) окремі оперативні підрозділи ДПС України за їх призначенням;

тактичні (окремі завдання) - частини та підрозділи ДПС України.

Виконання завдань має охоплювати не тільки безпосередні дії під час певних конфліктних (кризових) ситуацій, а й завчасну спільну підготовку сил i ïx ресурсне забезпечення.

Для цього формують матрицю завдань, у якій раціонально розподіляють їх між ДПС України та складовими сектору безпеки і оборони. Матриця має містити вихідні дані для планування кожної складової, щоб мати можливість залучати оптимальну кількість сил, забезпечувати їх ефективне застосування та економію ресурсів.

Опис умов виконання визначених завдань i факторів, які впливатимуть на їх виконання i сукупно становитимуть вимоги до оперативно-службових спроможностей.

Для опису оперативно-службових спроможностей ураховують умови (географічні, кліматичні, суспільно-політичні, військові, техногенні, криміногенні тощо), у яких триватиме виконання завдань за визначеними сценаріями (ситуаціями). До того ж використовують стандартні каталоги умов, які містять інформацію за трьома напрямами: фізичне середовище; умови застосування сил; цивільне середовище або суспільство.

Крім того використовується Орієнтовний перелік типових організаційних структур, а також орієнтовний каталог спроможностей типових організаційних структур сил i засобів ДПС України, які містять опис характеристик (вимог) основних спроможностей завчасно визначеного переліку базових (типових) структур.

Зазначений каталог розробляють i уточнюють 3 урахуванням надходження на озброєння нових зразків ОВТ, інженернотехнічного забезпечення, проведення організаційних заходів, розвитку форм i способів застосування сил.

Перелік умов і критеріїв виконання завдань за всіма визначеними сценаріями - це вимоги до оперативно-службових спроможностей, у яких визначено кількісні показники для реальних умов, що можуть виникнути під час виконання завдань. Вимоги грунтуються на стандартних характеристиках, визначених керівними документами, але кількісні їх показники можуть відрізнятися від стандартних і відповідати реальним умовам.
Перелік умов i критеріїв виконання завдань формують за окремими напрямами (категоріями): готовність сил; оперативні заходи; наявність резервів; застосування сил; управління та зв'язок; логістика (тилове, технічне та медичне забезпечення); живучість і захист сил тощо.

Визначення стандартів виконання завдань передбачає добір згідно зі стандартом відповідного зразка озброєння та військової техніки, інженерно-технічного забезпечення, рівня управління прикордонного підрозділу або за категоріями (складовими) оперативнослужбових спроможностей (готовність до виконання, оперативні заходи, наявність резервів, застосування, управління силами та зв'язок, логістика, живучість і захист сил.

Типову структуру сил ДПС України використовують для опису спроможностей як розрахункову (еталонну) одиницю.

Згідно 3 чинними в Україні концептуальними документами $[2,3]$ стратегічне планування в секторі безпеки i оборони проводять за адаптованими в Україні стандартами держав - членів НАТО.

Визначення вимог до спроможностей сил i засобів, необхідних для кожного сценарію та можливих ситуацій, для 3'ясування сумарних спроможностей сил i засобів, які необхідно мати для ефективного реагування на визначені загрози. Приклад визначення сценарію розвитку обстановки на ділянці відповідальності прикордонного загону та загону морської охорони у разі ускладнення обстановки наведений у табл. 1.

У науковій публікації [10] авторами наведено підхід, за яким можна визначити вимоги до спроможностей сил за певною послідовністю дій, а також поєднати інформацію про наявні спроможності, поставлені завдання, умови їх виконання та прогнозовані сценарії застосування сил. Відповідно, пропонується аналогічна послідовність дій для визначення вимог до спроможностей, а також конкретний варіант виконання визначених завдань за одним зі сценаріїв, а саме:

розробляється перелік імовірних сценаріїв застосування сил і засобів ДПС України;

готується список завдань для виконання визначеними силами у зазначеній конфліктній (кризовій) ситуації;

окреслюються умови виконання визначених завдань (фізичні, військові, цивільні фактори впливу) та складають список 
умов, що впливають на виконання визначених завдань;

розробляються стандарти як мінімально необхідні вимоги до виконання певного завдання у визначених умовах;

формується каталог типових структур

сил $\mathrm{i}$ засобів ДПС України 3 описом характеристик (вимог) основних оперативнослужбових спроможностей із завчасно визначеного переліку базових частин i підрозділів, органів управління, окремих засобів, а також систем i програмного забезпечення.

Таблиця 1

Сценарій розвитку обстановки на ділянці відповідальності прикордонного загону та загону морської охорони у разі ускладнення обстановки

\begin{tabular}{|c|c|c|c|c|c|c|c|}
\hline Загрози & $\begin{array}{c}\text { Сценарій } \\
\text { дій } \\
\text { порушника }\end{array}$ & $\begin{array}{l}\text { Кризові } \\
\text { ситуації }\end{array}$ & $\begin{array}{c}\text { Ступінь } \\
\text { залучення сил } \\
\text { i засобів } \\
\text { противника }\end{array}$ & $\begin{array}{c}\text { Формулювання } \\
\text { завдання } \\
\text { прикордонному } \\
\text { загону }\end{array}$ & $\begin{array}{c}\text { Наявні } \\
\text { спроможності } \\
\text { прикордонного } \\
\text { загону } \\
\end{array}$ & \begin{tabular}{|c|} 
Сили і засоби \\
ЗС України \\
(взаємодіючі \\
підрозділи)
\end{tabular} & $\begin{array}{c}\text { Необхідні } \\
\text { спроможності } \\
\text { прикордонного } \\
\text { загону }\end{array}$ \\
\hline $\begin{array}{c}\text { Збройна } \\
\text { агресія РФ }\end{array}$ & $\begin{array}{c}\text { Висадка } \\
\text { морського } \\
\text { десанту на } \\
\text { узбережжі } \\
\text { України }\end{array}$ & $\begin{array}{c}\text { Збройне } \\
\text { вторгнення } \\
\text { за } \\
\text { допомогою } \\
\text { морської } \\
\text { техніки на } \\
\text { територію } \\
\text { України }\end{array}$ & $\begin{array}{c}\text { ПСКА на } \\
\text { повітряній } \\
\text { подушці, малі } \\
\text { катера під } \\
\text { вогневим } \\
\text { прикриттям } \\
\text { ПСКР }\end{array}$ & $\begin{array}{c}\text { Відбиття зброй- } \\
\text { ного нападу та } \\
\text { недопущення } \\
\text { підходу } \\
\text { морських сил та } \\
\text { засобів до } \\
\text { узбережжя } \\
\text { України }\end{array}$ & $\begin{array}{c}\text { Сили та } \\
\text { засоби 3МО } \\
\text { (КрМО, } \\
\text { КаМО, } \\
\text { МКаМО) }\end{array}$ & \begin{tabular}{|c|} 
Висвітлення \\
надводної \\
обстановки \\
ПТС \\
прикриття \\
узбережжя \\
ЗС України \\
(берегова \\
артилерія)
\end{tabular} & $\begin{array}{c}\text { Сили та засоби } \\
\text { ЗМО (КрМО, } \\
\text { КаМО, } \\
\text { МКаМО), } \\
\text { протидивер- } \\
\text { сійнігрупи }\end{array}$ \\
\hline $\begin{array}{c}\text { України з } \\
\text { проведенням } \\
\text { морських та } \\
\text { сухопутних } \\
\text { операцій } 3 \\
\text { рішучими } \\
\text { воєнно- } \\
\text { політичними } \\
\text { цілями }\end{array}$ & $\begin{array}{c}\text { Обстріл } \\
\text { території } \\
\text { України } 3 \\
\text { території } \\
\text { РФ }\end{array}$ & \begin{tabular}{|c|} 
Обстріл \\
пунктів \\
управління, \\
нарядів та \\
підрозділів \\
ДПС України \\
на узбережжі \\
та іншої \\
інфраструк- \\
тури
\end{tabular} & \begin{tabular}{|c} 
Використання \\
систем \\
залпового \\
вогню, \\
ракетних \\
комплексів. \\
Використання \\
озброєння 3 \\
малих катерів \\
по береговій \\
смузі. \\
Обстріл 3 \\
використанням \\
авіації та БПЛА
\end{tabular} & \begin{tabular}{|c|} 
Відбиття \\
збройного нападу \\
та недопущення \\
ведення вогню по \\
території України. \\
Викриття місць \\
знаходження \\
агресора, \\
передавання даних \\
на ЦУС для \\
залучення \\
сил і засобів \\
старшого \\
начальника \\
для знищення \\
противника
\end{tabular} & $\begin{array}{c}\text { Сили і засоби } \\
\text { прикордонного } \\
\text { загону, ЗМО } \\
\text { (КрМО, } \\
\text { КаМО, } \\
\text { МКаМО) } \\
\text { висвітлення } \\
\text { надводної } \\
\text { обстановки } \\
\text { ПТС }\end{array}$ & $\begin{array}{c}\text { Прикриття } \\
\text { узбережжя } \\
\text { ЗС України } \\
\text { (берегова } \\
\text { артилерія). } \\
\text { Військова } \\
\text { авіація. Сили } \\
\text { та засоби } \\
\text { ВМС, ППО }\end{array}$ & $\begin{array}{c}\text { Сили та засоби } \\
\text { прикордонного } \\
\text { загону, ЗМО } \\
\text { (КрМО, КаМО, } \\
\text { МКаМО) } \\
\text { висвітлення } \\
\text { надводної } \\
\text { обстановки } \\
\text { ПТС }\end{array}$ \\
\hline
\end{tabular}

За результатами формується Каталог спроможностей типових структур ДПС України, а також визначаються вимоги до необхідних спроможностей сил і засобів, які залучатимуться до нейтралізації (запобігання, ліквідації наслідків) конфліктної (кризової) ситуації на державному кордоні певного сценарію та описують вимоги до спроможностей сил і засобів ДПС України для виконання визначених завдань за цим сценарієм.

Складовими спроможностей уважають: організацію, систему управління; кадрову систему та персонал; військову освіту і науку, спільну підготовку військ (сил); основні системи забезпечення ОВТ; матеріальне, інженерно-технічне та медичне забезпечення; прикордонну інфраструктуру.

Процедуру планування сил безпеки i оборони та спільної їх підготовки та застосування у конфліктних (кризових) ситуаціях воєнного характеру реалізовують на основі визначених ситуацій, завдань і вимог до оперативних (бойових) та службових спроможностей. Процедура передбачає оцінювання наявних спроможностей складових сил безпеки і оборони, визначення ïx відповідності вимогам до виконання завдань за окресленими сценаріями та відмінностей між необхідними і наявними спроможностями.

Визначені відмінності вважають основою для планування сил i засобів, 3'ясування необхідності утримувати наявні або формувати нові спроможності, чи нарощувати їх, або позбавлятися від зайвих.

Висновки. Планування оперативнослужбової діяльності ДПС України на сьогодні потребує вдосконалення завдяки активнішому впровадженню запропонованого МО України оборонного планування на основі спроможностей.

Упровадження у ДПС України планування на основі спроможностей дасть змогу якісніше здійснювати планування розвитку сил і засобів ДПС України; 
гармонізувати оборонне та бюджетне планування; відійти від ручного, ситуативного планування; у якості кінцевого результату зміцнити обороноздатність держави.

$\begin{array}{crr}\text { Запровадження у } & \text { діяльність } \\ \text { ДПС України планування } & \text { на } о \text { основі }\end{array}$ спроможностей дасть змогу поліпшити якість планування; підвищити здатність ДПС України до виконання завдань за призначенням; поширити отриманий досвід на інші складові сил оборони; забезпечити активне співробітництво України з НАТО 3 метою досягнення критеріїв, необхідних для набуття повноправного членства в Альянсі.

\section{СПИСОК ВИКОРИСТАНОЇ ЛІТЕРАТУРИ}

1. Оборонне планування на основі спроможностей: особливості та перспективи впровадження / I. С. Руснак та ін. Наука і оборона. 2017. № 2. С. 310.

2. Горбулін В. П. Розвиток оборонного планування як складової національної системи планування у сфері безпеки і оборони за умов наближення до процедур та стандартів НАТО : аналітична записка. Київ : НІСД, 2017. $17 \mathrm{c}$.

3. Буняк О. В., Бондарь Р. Г., $\quad$ Романюк I. M. Проблеми розвитку спроможностей сил оборони. Проблеми формування ефективної політики, системи планування $i$ управління ресурсами в секторі оборони з використанням сучасних євроатлантичних підходів : матеріали міжнар. наук.-практ. конф., м. Київ, 24 берез. 2017 р. Київ, 2017. C. 16-19.

Стаття надійшла до редакційної колегії 24.03.2021
4. Романченко І. С., Крикун П. М., Богданович Ю. В., Дєнєжкін М. М. Стан і перспективи розвитку системи оборонного планування в Збройних Силах України. Наука і оборона. 2017. № 1. С. 25-30.

5. Хоффман Ф. Г. Большая стратегия: основне соображения. Орбис. 2014. № 58 (4). С. 472-485. DOI: https://doi.org/10.1016/j.orbis.2014.08.002 (дата звернення: 15.02.2021).

6. Development and Implementation of the Target Function in the Decision-Making Process in the System of Providing the Military Security of the State / V. O. Kosevtsov et al. Eastern-European Journal of Enterprise Technologies. 2020. Vol. 5, No 3. P. 17-23. https://doi.org/10.15587/1729-4061.2020.215128.

7. National Resilienceas A Determinant of National Security of Ukraine / S. Bondarenko et al. Journal of Optimization in Industrial Engineering. 2021. Vol. 14, No 1. P. 111-117. DOI: https://doi.org/10.22094/ JOIE.2020.677837.

8. Оборонна реформа: системний підхід до оборонного менеджменту : монографія / А. Павліковський, В. Фролов, Ф. Саганюк та ін. ; за заг. ред. д-ра військ. наук А. Сиротенка. Київ : НУОУ, 2020. 274 с.

9. Оборонний огляд: український вимір 2014-2018 : монографія / Ф. Саганюк, А. Павліковський, П. Щипанський, В. Павленко та ін. ; за заг. ред. д-ра військ. наук, проф. І. Руснака. Київ : МО та ГШ ЗС України, НУОУ, 2019. 196 с.

10. Троцько В. В., Цурко Ю. В. Підхід до визначення вимог до необхідних можливостей для проведення оборонного огляду. Сектор безпеки i оборони України: теорія і практика : монографія. Київ : Академпрес, 2017. С. 68, 165-169.

\section{Improving defense planning in the State Border Guard Service of Ukraine}

\section{Annotation}

The article provides recommendations for improving the planning in the State Border Guard Service of Ukraine, which is based on the methodology of defense planning. Capability-based planning will allow for better planning of operational activities of the border agency and will ensure active cooperation between Ukraine and NATO in order to achieve the criteria necessary for full membership in the Alliance. The main tasks of planning in the State Border Guard Service of Ukraine on the basis of capabilities are formed, the principles and initial data are determined. Procedures for reviewing the state of the border agency are considered, namely environmental assessment, force planning, resource planning, risk assessment, formation of a promising model and structure of the State Border Guard Service of Ukraine that meets the accepted risks, preparation of development program documents. The process of developing the capacity of the department to perform certain tasks is defined and the main procedures are indicated. Requirements are identified for the capabilities of the forces and means required for each scenario and possible situations, to determine the total capabilities of the forces and means that must be available to respond effectively to identify threats. The procedure of planning security and defense forces and their joint training and application in conflict (crisis) situations of a military nature is implemented on the basis of certain situations, tasks and requirements for operational (combat) and service capabilities. The procedure involves assessing the available capabilities of the components of the security and defense forces, determining their compliance with the requirements for the tasks in the outlined scenarios and the differences between the required and available capabilities. The advantages of the implementation of capacity-based planning in the operational and service activities of the State Border Guard Service of Ukraine are determined.

Keywords: planning; capabilities; operational and service activities; forces and means; State Border Guard Service of Ukraine. 